doi: $10.35757 /$ KiS.2020.64.3.10

\begin{tabular}{|c|c|}
\hline KULTURA & $\begin{array}{l}\text { POLSKA AKADEMIA NAUK } \\
\text { KOMITET SOCJOLOGII } \\
\text { INSTYTUT STUDIÓW POLITYCZNYCH }\end{array}$ \\
\hline & $2020, \mathrm{nr}$ \\
\hline
\end{tabular}

MICHAE WYPYCH

Wydziat Psychologii, Uniwersytet Warszawski

KAMILA ZOCHNIAK

Wydziat Psychologii, Uniwersytet Warszawski

MICHAŁ BILEWICZ

Wydział Psychologii i Instytut Studiów Społecznych im. Roberta Zajonca, Uniwersytet Warszawski

\title{
MOWA NIENAWIŚCI JAKO STYGMATYZACJA \\ DOŚWIADCZENIE KONTAKTU Z MOWĄ NIENAWIŚCI WŚRÓD IMIGRANTÓW W POLSCE ORAZ STUDENTÓW Z ZAGRANICY*
}

W listopadzie 2019 roku studentka jednego z polskich uniwersytetów opublikowała $\mathrm{w}$ internecie film, w którym obraźliwie wypowiadała się o Ukraince, która usiadła w przedziale na jednym z zarezerwowanych przez tę studentkę miejsc. Używała dehumanizującego języka i wyrażała swoje poczucie wyższości. Sprawa trafiła do władz uczelni oraz prokuratury i w konsekwencji dziewczyna wystosowała przeprosiny ${ }^{1}$. Przypadków tego typu nienawistnych wypowiedzi wobec Ukraińców ostatnio przybywa. W latach 2014-2016 zaobserwowano wśród Polaków, zarówno młodzieży, jak i dorosłych, wzrost częstości kontaktu z mową nienawiści

Adresy do korespondencji: michal.wypych@psych.uw.edu.pl, ORCID: 0000-0002-0475-7209; kamila.zochniak@psych.uw.edu.pl, ORCID: 0000-0002-0468-6471; bilewicz@ psych.uw.edu.pl, ORCID: 0000-0001-5027-1691

* Artykuł powstał w ramach projektu Sonata BIS Narodowego Centrum Nauki (UMO2017/26/E/HS6/00129). Autorzy dziękują zespołowi badawczemu przeprowadzającemu badanie poczucia bezpieczeństwa studentów zagranicznych na Uniwersytecie Warszawskim (Kamila Ferenc, Agnieszka Grzybowska, Mateusz Jaworski, Olga Kuzawińska, Ekaterina Tcypysheva, Wojciech Wilk, Jakub Wielgo). Badanie zrealizowane zostało w latach 2017-2018 przez Instytut Studiów Społecznych UW pod opieką merytoryczną Michała Bilewicza.

${ }^{1}$ Studentka miała obrażać Ukrainkę. Zareagowała uczelnia, prokuratura wszczęła dochodzenie, 26 listopada 2019, tvn24.pl (https://tvn24.pl/wiadomosci-z-kraju,3/olsztyn-studentka-obra zala-ukrainke-w-internecie-dochodzenie-prokuratury-reakcja-uczelni,988427.html? $\mathrm{h}=2 \mathrm{e} 2 \mathrm{f}$ ). 
skierowaną przeciw Ukraińcom (Winiewski i in. 2017). Mowę nienawiści można określić — za definicją Rady Europy — jako takie wypowiedzi, które rozpowszechniają, promują lub usprawiedliwiają nienawiść etniczną, rasową, ksenofobię, antysemityzm lub inne rodzaje nietolerancji i uprzedzeń. Wypowiedzi tego typu nie tylko są wyrazem uprzedzeń i niesprawiedliwych opinii o mniejszościach, ale jednocześnie w określony sposób oddziałują na grupy, przeciw którym są skierowane (Butler 2010).

Przyjrzymy się tu skali doświadczania mowy nienawiści wśród imigrantów ukraińskich mieszkających w Polsce oraz wśród zagranicznych studentów Uniwersytetu Warszawskiego, największej polskiej uczelni. Celem przeprowadzonych analiz jest oszacowanie psychologicznych i społecznych konsekwencji codziennego kontaktu z agresją werbalną.

\section{KONSEKWENCJE MOWY NIENAWIŚCI}

Społeczne i psychologiczne konsekwencje agresji werbalnej przez wiele lat pozostawały zaniedbanym obszarem badań naukowych. Słowa nie były bowiem traktowane jako źródło faktycznej traumatyzacji grup mniejszościowych czy imigranckich. Laura Leets i Howard Giles (1997) w analizie psychologicznych konsekwencji mowy nienawiści zwrócili uwagę na potrzebę przyjrzenia się negatywnym skutkom takich zachowań wśród mniejszości i imigrantów. Badania konsekwencji nienawistnych wypowiedzi wskazały, że mają one charakter emocjonalnej i psychicznej krzywdy. Autorzy wyjaśniają, że ból psychiczny związany z rasistowskimi wypowiedziami był dla ofiar trudny do zniesienia. Definicja bólu psychicznego i emocjonalnego nie jest klarowna, ale osoby badane oceniały ten rodzaj bólu jako doświadczenie dotkliwsze niż doznanie bólu fizycznego. Badanie Leets i Gilesa ukazało, że istnieje potrzeba stworzenia nowego słownictwa, które odpowiednio opisywałoby ból psychiczny doznawany przez ofiary przemocy, przyjmującej między innymi postać krzywdzącego języka².

Wyniki badań wskazują, że mowa nienawiści może być przez ofiarę postrzegana jako wydarzenie traumatyczne. Nienawistne wypowiedzi często są odbierane jako zbyt przytłaczające, co skutkuje wyczerpaniem zasobów potrzebnych do radzenia sobie ze stresem w codziennych sytuacjach. Leets (2002) zaproponowała trzystopniowy model reakcji na doświadczenie mowy nienawiści. W fazie pierwszej - początkowej dezorganizacji

2 Leets i Giles koncentrują się na mowie nienawiści skierowanej przeciwko mniejszościom, ponieważ większość definicji tego zjawiska dotyczy właśnie języka krzywdzącego grupy mniejszości. Szerszą analizę definicji mowy nienawiści zob. Brown 2017. 
(uderzenia) - bezpośrednio po zdarzeniu traumatycznym ofiary wykazują reakcje emocjonalne, takie jak gniew, zaprzeczenie czy bezbronność, a później często pojawiają się huśtawki emocjonalne bądź obwinianie siebie o winy innych. Następna faza - walka o dostosowanie (odbicie) to wypracowanie negatywnych postaw wobec sprawców mowy nienawiści. Ostatni etap - reorganizacja (odbudowa) - obejmuje próby zmiany zachowań oraz radzenia sobie $z$ napotkanym hejtem. Konsekwencje emocjonalne dotyczące dwóch pierwszych faz to skutki krótkoterminowe, natomiast reorganizacja, skutkująca zmianą postaw i zachowań, jest skutkiem długoterminowym (Leets, Giles 1999).

Trzeba zaznaczyć, że badania Leets i Gilesa (1999) dotyczyły nie tylko na kontaktów interpersonalnych, lecz również relacji międzygrupowych. Co ciekawe, chociaż obraźliwe wypowiedzi były najczęstszą przyczyną zgłaszania przestępstw popełnianych przez członków grup obcych, kategoria przestępstw tego rodzaju okazała się najczęściej pomijaną w sprawozdaniach i statystykach.

Należy zwrócić uwagę, że ocena stopnia obraźliwości nienawistnych wypowiedzi zależy od tego, która grupa ją ocenia grupy. Wyniki przedstawianych przez nas badań wskazują, że bezpośrednia mowa nienawiści jest oceniania jako bardziej obraźliwa przez osoby z grupy większościowej. Członkowie grupy mniejszościowej zaś bardziej negatywnie oceniali nienawistne wypowiedzi wyrażone w sposób pośredni. Postrzeganie wypowiedzi jako bardziej lub mniej krzywdzącej może również zależeć od jej źródeł. Wypowiedź Amerykanów pochodzenia azjatyckiego przez grupę większościową była odbierana jako bezpośredni i jawny „atak”, podczas gdy tę samę treść wypowiadaną przez białych Amerykanów odbierano jako pośrednią i niejawną.

Na podstawie analiz danych archiwalnych oraz badań empirycznych stwierdzono (Leader, Mullen, Rice 2009), że stopień złożoności wypowiedzi na temat grupy wywiera silniejszy wpływ na jej wykluczenie niż jej nacechowanie emocjonalne. Badacze manipulowali złożonością wypowiedzi za pomocą serii stwierdzeń o grupie mniejszościowej, które dotyczyły różnych kategorii opisu członków tych grup, na przykład wyglądu, nawyków żywieniowych czy imion. Osoby badane czytały wypowiedzi na temat tylko jednej kategorii, na przykład wyglądu, albo wypowiedzi złożone, zawierające odniesienia do kilku kategorii, zarówno wypowiedzi na na temat wyglądu, jak i na przykład imion. Mniejsza złożoność wypowiedzi (pięć wypowiedzi na temat inteligencji członka grupy obcej o różnym stopniu nacechowania negatywnego) wywoływała mniej przychylne reakcje osób badanych niż wypowiedzi o większej złożoności (dwie wypowiedzi na te- 
mat inteligencji, dwie wypowiedzi na temat charakteru i jedna wypowiedź na temat wyglądu członka grupy obcej o tym samym stopniu nacechowania negatywnego).

Ukazano również (Mullen, Smyth 2004), że publiczna ekspresja mowy nienawiści w stosunku do grup mniejszościowych wiązała się z gorszym dobrostanem psychicznym członków tych grup oraz wyższym wskaźnikiem popełniania samobójstw. Badania wskazują również (Mullen, Rice 2003), że publiczna mowa nienawiści wobec grup mniejszościowych wiązała się z wykluczeniem społecznym członków tych grup.

\section{Ukrywanie mniejszościowej tożsamości jako reakcja na dyskryminację}

Dyskryminowane grupy mniejszościowe często spotykają się również $z$ napiętnowaniem. Piętno można zdefiniować jako „atrybut dotkliwie dyskredytujący" (Goffman 2005). Należy zaznaczyć, że cecha, która w jednym kontekście jest piętnująca, w innym może taka nie być — piętno jest więc konstruowane społecznie. Na stygmatyzację narażone są różne grupy. Według Grvinga Goffmana (2005; por. Eidhiem 1969) piętnem może być również przynależność do danej grupy etnicznej lub religijnej.

Osoby należące do napiętnowanych grup mogą stosować różne strategie, by radzić sobie ze swoją sytuacją. Mogą umniejszać skalę dyskryminacji (Crosby 1984), mogą identyfikować się z inną grupą (Tajfel, Turner, 1979) lub działać na rzecz grupy własnej (Molero i in. 2011). Jako jedną z możliwych reakcji na dyskryminację Gordon Allport (1954) wskazuje odrzucanie przynależności do grupy własnej w interakcjach z członkami grupy dominującej. Pozwala to uchodzić za członka grupy większościowej - osoby należące do dyskryminowanej lub stygmatyzowanej mniejszości mogą $\mathrm{w}$ ten sposob unikać dyskryminacji. Również Erving Goffman (2005) wskazuje, że częstą reakcją na stygmatyzację jest ścisłe kontrolowanie sposobu, w jaki jednostka prezentuje się innym. Dzięki temu może ukrywać piętnowany atrybut, zwłaszcza gdy nie jest on zbyt widoczny.

Ukrywanie przynależności do napiętnowanej grupy może wydawać się efektywną strategią radzenia sobie $z$ piętnem, ma jednak wiele negatywnych konsekwencji. Osoby często ją stosujące deklarują niższy dobrostan psychiczny (Molero i in. 2011; Quinn, Earnshaw 2013). Strategia ta może również prowadzić do poczucia nieautentyczności i wykluczenia społecznego (Newheiser, Barreto 2014).

Badania dotyczące stygmatyzacji ukraińskiej tożsamości w Polsce (Matysiak 2014) ujawniają konkretne sposoby radzenia sobie $z$ byciem na- 
piętnowanym. Ponieważ istotnym wyznacznikiem tożsamości społecznej jest język (Giles, Johnson 1987), w przypadku imigrantów jedną z możliwych strategii pozostania nierozpoznanymi w przestrzeni publicznej jest kontrolowanie języka, którym się posługują (Valenta 2009; Monzó, Rueda 2009). W interakcjach z członkami grupy dominującej osoby z grupy dyskryminowanej mogą dostosowywać swój język do rozmówców, tak by sprawiać wrażenie, że są do nich bardziej podobni. Unikanie mówienia po ukraińsku lub rosyjsku może być zatem sposobem na ukrycie tożsamości Strategię taką można określić - za teorią akomodacji komunikacji mianem konwergencji (Giles, Ogay 2007).

Unikanie mówienia w swoim języku może pojawić się również w interakcji z członkami grupy własnej. Imigranci doświadczający dyskryminacji lub wystawieni na mowę nienawiści skierowaną przeciw ich grupie będą unikać używania swojego języka w obecności innych członków grupy własnej - porzucą wówczas identyfikację z grupą własną i będą mówić w języku grupy dominującej (Giles, Johnson, 1987). W sferze międzypokoleniowej transmisji języka stać może za tym obawa, że dzieci doświadczą dyskryminacji lub będą gorzej sobie radziły, mówiąc w języku ojczystym rodziców (Evans 1996).

\section{PRZYPADKI DYSKRYMINACJI UKRAIŃCÓW W POLSCE}

Oszacowanie liczby osób pochodzenia ukraińskiego przebywających w Polsce jest trudne, gdyż dane dotyczące formalnego zamieszkania Ukraińców w Polsce nie obejmują osób pracujących bądź wynajmujących mieszkania bez umowy. Według Narodowego Spisu Powszechnego Ludności i Mieszkań w roku 2011 w Polsce zamieszkiwało 227,5 tys. osób pochodzących z Ukrainy (Brunarska, Grotte, Lesińska 2012), natomiast według oszacowań Departamentu Statystyki Narodowego Banku Polskiego w roku 2017 przebywało w naszym kraju około 900 tysięcy obywateli Ukrainy (Chmielewska, Dobroczek, Panuciak 2018). Przybysze z Ukrainy stanowią największą grupę imigrantów w Polsce i co roku przybywa coraz więcej osób posiadających obywatelstwo ukraińskie, głównie w celach zarobkowych. Mniejszość ukraińska oraz imigranci z Ukrainy stanowią też jedną z najczęściej stygmatyzowanych grup w Polsce, co przejawia się na wielu płaszczyznach. Jedną z praktyk dyskryminacyjnych jest mowa nienawiści.

Według definicji Rady Europy mowa nienawiści to:

„[...] wszystkie formy ekspresji, które rozpowszechniają, podżegają, wspierają lub usprawiedliwiają nienawiść rasową, religijną, ksenofobię, antysemityzm lub inne formy nienawiści wynikające z nietolerancji, łącznie 
z nietolerancją wyrażoną za pomocą agresywnego nacjonalizmu i etnocentryzmu, dyskryminacją i wrogością wobec przedstawicieli mniejszości, imigrantów i osób obcego pochodzenia" (Mowa nienawiści wg Rady Europy 2020).

Według polskich aktów prawnych mowa nienawiści jest niezgodna $\mathrm{z}$ prawem, a jej ofiarę chronią przepisy zarówno kodeksu karnego, jak i kodeksu cywilnego (Mowa nienawiści. Prawo polskie 2020). Trzeba jednak zaznaczyć, że w przepisach obowiązujących w Polsce nie została zawarta definicja mowy nienawiści (Sobański 2019), co jest przyczyną trudności $z$ udowodnieniem winy sprawcom tego rodzaju przestępstw.

Analizy prowadzone przez społeczność ukraińską w Polsce (Tyma 2019) przedstawiają przypadki praktyk dyskryminacyjnych wobec mniejszości ukraińskiej, między innymi niszczenia miejsc kultu i pamięci czy nienawistne wypowiedzi osób publicznych. Oto przykłady: w 2019 roku w marcu w Warszawie przez dwójkę pasażerów został pobity kierowca pochodzenia ukraińskiego ${ }^{3}$; a w kwietniu we Wrocławiu taksówkarz celowo potrącił oraz przejechał rowerzystę narodowości ukraińskiej ${ }^{4}$. W listopadzie 2018 roku we Fredropolu dokonano zniszczeń nagrobków na dwóch ukraińskich mogiłach. Jedna $z$ mogił pochodziła $z$ XIX wieku, druga natomiast należała do ks. Iwana Hnatyszczaka, dawnego proboszcza parafii w Korczminie (Tyma 2019). Podobnych historii można usłyszeć coraz więcej.

Ukraińcy migrują do Polski w celach zarobkowych (Polko 2018), główną tego przyczyną jest niekorzystna sytuacja ekonomiczna w ich kraju (Dąbrowski 2012). Polscy pracodawcy często wykorzystują trudne położenie ukraińskich pracowników (Klebeko 2018). Zdarzają się incydenty świadczenia pracy bez umowy czy oszustwa ze strony pracodawców, na przykład niewypłacanie zasłużonych zarobków bądź zmniejszanie należnej wypłaty. Pokrzywdzeni podkreślali częste oferowanie przez pracodawców niewłaściwych umów oraz niedogodnych warunków zamieszkania w Polsce. Wspominali o mieszkaniu w salach wieloosobowych, braku łóżek bądź o styczności w pracy z alergicznymi substancjami bez odpowiedniej ochrony. Istotnym skutkiem złych warunków życia oraz pracy jest pogarszanie się zdrowia - zarówno fizycznego, jak i psychicznego (Dąbrowski 2012). Wielokrotnie można było usłyszeć o przemocy werbalnej wobec

\footnotetext{
3 Pobili kierowcę Ubera. Bo jest Ukraińcem i nie wtaczyt disco polo, 10 marca 2019, wyborcza.pl (https://warszawa.wyborcza.pl/warszawa/7,54420,24536030,pobili-kierowce-uberabo-jest-ukraincem-i-nie-wlaczyl-disco.html).

${ }^{4}$ Wroctawianie i Caritas wspierają Ukrainca przejechanego przez taksówkarza, 4 maja 2019, wyborcza.pl (https://wroclaw.wyborcza.pl/wroclaw/7,35771,24751392,wroclawianie-i-caritas -wspieraja-ukrainca-przejechanego-przez.html).
} 
imigrantów z Ukrainy, również ze strony osób publicznych ${ }^{5}$, Na obraźliwe wypowiedzi reagowały różne organizacje, między innymi Związek Ukraińców w Polsce czy Fundacja Współpracy Polsko-Ukraińskiej (Jurek 2018).

Według raportu Mniejszość ukrainska i migranci z Ukrainy w Polsce. Analiza dyskursu (Tyma 2019) od roku 2016 wraz ze wzrostem liczby imigrantów pochodzenia ukraińskiego $\mathrm{w}$ Polsce nastąpił również istotny wzrost liczby przypadków przemocy wobec przyjezdnych, zarówno fizycznej, jak i symbolicznej. Z kolei raport $z$ badań zleconych przez Biuro Instytucji Demokratycznych i Praw Człowieka OBWE (Office for Democratic Institutions and Human Rights) wskazuje, że około połowy przestępstw zgłaszanych przez Ukraińców w latach 2016 i 2017 stanowiły przestępstwa $z$ nienawiści (ODIHR 2018). Sześćdziesiąt procent ankietowanych uważało, że motywacją do popełnienia przestępstwa były uprzedzenia związane z pochodzeniem, religią bądź kolorem skóry ofiary. Najczęściej wymienianym zdarzeniem były zniewagi, o których wspomniało $17 \%$ ankietowanych Ukraińców, na drugim miejscu znalazły się groźby $-7 \%$ badanych. Wiele tego rodzaju przestępstw nie jest zgłaszanych z powodu nieznajomości języka polskiego, barier kulturowych, przewlekłości procedur prawnych, nieznajomości własnych praw, niechęci ze strony niektórych przedstawicieli organów ścigania do przyjmowania takich zgłoszeń czy wręcz negatywnego nastawienia do cudzoziemców (Tyma 2019). Osoby badane uważały swoje pochodzenie za główną motywację najpoważniejszych przestępstw, których padły ofiarą. Dlatego też doświadczenie przemocy skutkowało między innymi unikaniem mówienia w języku ukraińskim w miejscach publicznych (ODIHR 2018).

Skutki psychologiczne doświadczeń dyskryminacji oraz przemocy werbalnej, jakie odczuwają imigranci z Ukrainy, to problem wciąż mało zbadany. Istniejące dane wskazują na związki występowania zespołu stresu pourazowego (posttraumatic stress disorder - PTSD) z doświadczeniem przestępstwa $z$ nienawiści. Nie stwierdzono tego w wypadku mniejszości ukraińskiej, ale $18 \%$ ankietowanych Ukraińców, którzy doświadczyli przestępstw z nienawiści, wskazywało objawy ciężkiej depresji (ODIHR 2018).

Porównania danych dotyczących rozpowszechnienia antyukraińskiej mowy nienawiści wśród polskiej populacji w roku 2014 oraz 2016 wskazują na znaczne nasilenie tego zjawiska, zarówno w prasie, telewizji, radiu, jak i w internecie (Winiewski i in. 2017). Najwyższy wzrost styczności $z$ antyukraińską mową nienawiści $w$ internecie odnotowano wśród mło-

${ }^{5}$ Wiele kontrowersji wzbudziły wypowiedzi Jakuba Wojewódzkiego, Michała Figurskiego oraz Bartosza Węglarczyka. 
dzieży. W roku 2014 z antyukraińskimi wypowiedziami w internecie spotkało się około $50 \%$ młodych ludzi, a w roku 2016 było to już $71 \%$. Wyniki tych badań ukazują, że najliczniejszą kategorię treści (aż 79,2\%) stanowiły te, które koncentrowały się na historycznych ukraińskich zbrodniach wobec Polaków.

Interesujący wydaje się związek między postrzeganiem stopnia obraźliwości nienawistnych wypowiedzi a odczuciem zagrożenia symbolicznego ze strony mniejszości ukraińskiej (Bilewicz i in. 2014). Osoby, które uważały Ukraińców za grupę zagrażającą narodowym wartościom Polaków, nienawistne komentarze skierowane do Ukraińców postrzegały jako mniej krzywdzące. Ponadto jednym z przejawów przemocy symbolicznej jest obinianie ofiar o wszelkie własne niepowodzenia, zwłaszcza bezrobocie. Mniejszość ukraińska wskazuje, że Polacy mają skłonność do okazywania wyższości, racjonalizują przy tym uprzedzenia i usprawiedliwiają dyskryminację Ukraińców (Jurek 2018). Badania przeprowadzone na Uniwersytecie Opolskim (Wiśniewski 2018) wykazały, że obraz studenta z Ukrainy w oczach studenta Polaka najczęściej jest negatywny oraz związany $z$ niechęcią bądź uprzedzeniami. W obrazie tym stereotypowo pojawiały: niekulturalne zachowanie, poczucie wyższości okazywane Polakom, brak dążenia do integracji (izolacjonizm) czy sugestie dotyczące potencjalnego „zabierania miejsc pracy”. Powyższe rezultaty mogą świadczyć o stosunkowo trwałym negatywnym wizerunku Ukraińca w Polsce (Jurek 2018). Jednocześnie członkowie mniejszości ukraińskiej w większości sądzą, że są przez Polaków odbierani negatywnie.

\section{STUDENCI Z ZAGRANICY WOBEC DYSKRYMINACJI}

Według raportu Study in Poland (Fundacja edukacyjna Perspektywy 2017) w ostatnich latach w Polsce wzrasta ilość cudzoziemców uczących się na uczelniach wyższych. W roku akademickim 2016/2017 w całym kraju studiowało 65793 studentów zagranicznych ze 166 krajów. Zdrowie psychiczne i fizyczne studentów zagranicznych było przedmiotem wielu badań w Australii, Stanach Zjednoczonych czy Wielkiej Brytanii. Badania przeprowadzone w Australii (Rosenthal, Russell, Thomson 2006) wykazały istnienie kilku czynników ryzyka, które wpływają na zdrowie zagranicznych studentów. Należały do nich aktywność seksualna bez zabezpieczenia, zażywanie narkotyków, palenie papierosów oraz hazard. W Stanach Zjednoczonych ustalono, że głównym czynnikiem utrudniającym adaptację studentów zagranicznych na tamtejszych prywatnych uczelniach była niedostateczna znajomość języka (Galloway, Jenkins 2005). 
Źródłem istotnych problemów są dla studentów zagranicznych kwestie kulturowe. Studenci z Azji odczuwali w związku tym znacznie wyższy poziom stresu w porównaniu z innymi studentami. Wiele studentek noszących tradycyjne stroje, na przykład sari lub hidżab, spotykało się z trudnościami na uczelni i mówiło o nieprzyjemnych doświadczeniach związanych $z$ ich ubiorem (Lee, Rice 2007). Badania nad studentami zagranicznymi w Stanach Zjednoczonych pokazują, że różnice kulturowe są szczególnie widoczne w obszarze relacji społecznych. Nieporozumienia i zakłopotanie ze strony studentów zagranicznych często okazywały się skutkiem nietrafnej interpretacji intencji Amerykanów. Na przykład zdawkowe uprzejmości, takie jak „zadzwonię do ciebie”, były często odbierane jako oznaki szczerego zainteresowania oraz chęci nawiązania przyjaźni bądź relacji romantycznej (Mori 2000).

Młodym ludziom wyjeżdżającym na studia za granicę może towarzyszyć stres akulturacyjny oraz różne symptomy pogorszenia zdrowia psychicznego. Dostrzeżona bądź antycypowana niechęć ze strony mieszkańców kraju, w którym przebywaja, może wywoływać gniew przenoszony na niechęć do kultury tego kraju bądź kraju pochodzenia. Tęsknota za domem może prowadzić do odczuwania bolesnej izolacji, samotności oraz depresji. Frustrację przybyszy może również wywoływać fakt że w kraju, w którym studiują, mają niższy status socjoekonomiczny niż w kraju pochodzenia (Mori 2000). Dowodzą tego badania wskazujące, że zagraniczni studenci z zamożniejszych krajów europejskich zwykle zgłaszają niższy poziom dyskryminacji aniżeli studenci spoza Europy (Poyrazli, Lopez 2007). Można zatem przypuszczać, że doświadczanie kontaktu z mową nienawiści jest poważnym wyzwaniem $\mathrm{w}$ toku adaptacji studentów zagranicznych. Bycie ofiarą mowy nienawiści bowiem może komunikatem niskim statusie jego odbiorcy, uświadamia mu własną kulturową odrębność, odrzucenie, a nieraz wręcz niekompetencję kulturową. Wszystkie te czynniki przekładają się na gorsze funkcjonowanie psychospołeczne studentów zagranicznych.

\section{PSYCHOSPOŁECZNE NASTĘPSTWA MOWY NIENAWIŚCI WŚRÓD UKRAIŃCÓW I STUDENTÓW ZAGRANICZNYCH W POLSCE}

Konsekwencje doświadczenia bycia ofiarą mowy nienawiści wśród grup mniejszościowych i imigranckich w Polsce nie były dotychczas przedmiotem badań empirycznych. Odpowiedź na pytanie, czy codzienny kontakt z mową nienawiści przekłada się na pogorszenie zdrowia psychicznego, a jednocześnie na trudności w zakresie funkcjonowania społecznego 
i ukrywanie tożsamości, ma znaczenie zarówno teoretyczne, jak i praktyczne. $Z$ jednej strony pozwala na lepsze wyjaśnienie procesów stygmatyzacji imigrantów i mniejszości; $z$ drugiej zaś ułatwia zaplanowanie działań asymilacyjnych wobec naznaczonych społecznie grup. W przeprowadzonych badaniach skupiliśmy się na dwóch grupach $z$ doświadczeniem migracji: (1) ukraińskich imigrantach zarobkowych oraz (2) studentach zagranicznych największej polskiej uczelni, Uniwersytetu Warszawskiego. Celem naszym było zbadanie skali kontaktu z mową nienawiści wśród obu tychch grup, określenie siły związków ekspozycji na mowę nienawiści ze zdrowiem i dobrostanem psychicznym oraz oszacowanie siły związków ekspozycji na mowę nienawiści z ukrywaniem swojej tożsamości poprzez unikanie używania języka ukraińskiego lub rosyjskiego w obecności osób $z$ grupy dominującej i własnej.

W celu uzyskania niezbędnych informacji zostały zrealizowane dwa badania kwestionariuszowe, a na zebranych w ten sposób danych przeprowadzono analizy korelacyjne. Takie metody badawcze pozwalają na zebranie dużych prób badawczych oraz analizę związków między wieloma zmiennymi. Należy jednak pamiętać, że zbiorowości badane zastosowaną przez nas metodą nie były reprezentatywne dla populacji ukraińskich imigrantów i studentów zagranicznych w Polsce oraz że na podstawie analiz korelacyjnych nie da się jednoznacznie wyprowadzić wniosków o zależnościach przyczynowych.

Badanie doświadczenia mowy nienawiści kierowanej do ukraińskich imigrantów

W celu określenia skali kontaktu z mową nienawiści doświadczanego przez imigrantów ukraińskich oraz jego psychospołecznych następstw przeprowadziliśmy badanie za pomocą kwestionariusza on-line dystrybuowanego wśród środowisk imigranckich w Polsce (za pośrednictwem firm rekrutujących pracowników ukraińskich, w miejscach tranzytu, w środowiskach studenckich oraz poprzez organizacje pozarządowe). Celem było stworzenie próby zróżnicowanej wiekowo oraz socjo-ekonomicznie. Kwestionariusz był dostępny w dwóch wersjach językowych: po ukraińsku i rosyjsku. Wypełniły go 833 osoby. Z analiz wykluczono 107 osób, ponieważ nie zadeklarowały narodowości ukraińskiej. Wśród pozostałych $65,3 \%$ stanowiły kobiety, $34,6 \%$ mężczyźni, a $0,1 \%$ zadeklarowało inną płeć. Były to osoby w wieku od 17 do 72 lat $(M=28,3, S D=8,90)$. Jako swój pierwszy język $69,7 \%$ osób biorących udział w badaniu wskazało ukraiński, $18,7 \%$ rosyjski, $1,3 \%$ inny język ojczysty, a $10,2 \%$ nie udzieliło odpowiedzi na to pytanie. 
Wykorzystane skale. Uczestnikom badania pokazano trzy przykłady wypowiedzi przez przedstawicieli mniejszości ukraińskiej uznanych za mowę nienawiści skierowaną przeciw Ukraińcom (Bilewicz i in. 2014). Zadano im pytanie, jak często spotykają się z podobnymi wypowiedziami (skala odpowiedzi: 1 - nigdy, 5 - bardzo często). Następnie pytano o miejsca, w których badani spotykają się z takimi wypowiedziami.

Nasilenie objawów zespołu stresu pourazowego zmierzono za pomocą skali PTSD-8 (Posttraumatic Stress Disorder-8) (Hansen i in. 2010). Skala ta składa się z ośmiu pytań $(\alpha=0,86)$, na które udziela się odpowiedzi na skali od $1-$ nigdy do $4-$ często. Mierzy ona trzy aspekty PTSD: intruzję, unikanie myśli dotyczących traumatycznego zdarzenia i nadmierną czujność. Skala PTSD-8, oprócz mierzenia nasilenia objawów, pozwala również na stworzenie wskaźnika traumatyzacji. Generuje się go tworząc skalę binarną - za próg odcięcia uznaje się występowanie przynajmniej jednego symptomu z każdej podskali (Hansen i in. 2010).

Do pomiaru nasilenia objawów depresji wykorzystano skalę PHQ-9 (Patient Health Questionnaire-9) (Kroenke, Spitzer, Williams 2001). Mierzy ona częstość występowania symptomów depresji za pomocą dziewięciu pytań $(\alpha=0,87)$, na które osoby biorące udział w badaniu odpowiadały za pomocą skali od 1 -wcale nie dokuczały do 4 - codziennie dokuczały.

Samoocenę zmierzono za pomocą skali Morrisa Rosenberga (1965), która służy do oceny poziomu ogólnej samooceny, rozumianej jako względnie stała dyspozycja określana jako świadoma postawa - zarówno pozytywna, jak i negatywna - wobec Ja. Osoby biorące udział w badaniu proszono o ustosunkowanie się do dziesięciu stwierdzeń na skali od 1 — zdecydowanie się nie zgadzam do $4-z$ decydowanie się zgadzam. Rzetelność skali wynosiła $\alpha=0,85$.

Do pomiaru afektu zastosowano składająca się z dwudziestu pozycji skalę PANAS (Positive and Negative Affect Schedule) w wersji do pomiaru cechy (Watson, Clark, Tellegen, 1988). Mierzy ona, na podstawie samoopisu, afekt pozytywny oraz negatywny. Osoby biorące udział w badaniu określały, w jakim stopniu zazwyczaj odczuwają różne emocje na skali od 1 nieznacznie lub wcale do 5 - bardzo silnie. Dziesięć pozycji mierzyło pozytywny, a dziesięć negatywny afekt. W analizach wykorzystano średnie dla skal pozytywnego $(\alpha=0,86)$ i negatywnego afektu $(\alpha=0,91)$.

Aby zmierzyć, $w$ jakim stopniu imigranci z Ukrainy unikają używania swojego języka w obecności Polaków oraz osób z grupy własnej, stworzono dwie skale (obie w dwóch wersjach językowych). W obu wypadkach proszono o wskazanie na skali od 1 - nigdy do 5 - bardzo często, w jakim stopniu obecnie doświadczają wymienionych w pytaniu sytuacji. Pierwsza 
skala mierzyła unikanie mówienia w swoim języku w obecności Polaków i składała się z czterech stwierdzeń $(\alpha=0,85)$ : Nie mówię $z$ moimi przyjaciótmi/znajomymi po ukraińsku/rosyjsku w transporcie publicznym lub innych miejscach publicznych; Wolęnie używać ukraińskiego/rosyjskiego, gdy jestem z Polakami na imprezie lub $w$ pracy; Kiedy jestem $w$ autobusie lub innych miejscach publicznych, unikam odbierania telefonu, jeśli wiem, że musiałabym/musiałbym rozmawiać po ukraińsku/rosyjsku; Unikam mówienia po ukraińsku/rosyjsku, żeby ludzie nie wiedzieli, że jestem Ukrainka/Ukraińcem. Druga skala mierzyła, w jakim stopniu imigranci z Ukrainy unikają używania swojego języka w obecności osób $z$ grupy własnej. Skala ta składała się z dwóch pozycji $(\alpha=0,82)$ : Unikam mówienia po ukrainsku/rosyjsku z innymi Ukraińcami, bo obawiam się, że już trochę wyszedłem/wyszłam z wprawy; Nie potrafię się przemóc, żeby mówić po ukrainsku/rosyjsku do dzieci (swoich bądź innych).

Mowa nienawiści - jak często i gdzie się pojawia? Blisko $60 \%$ badanych wskazało, że spotykają się z mową nienawiści skierowaną przeciw Ukraińcom, przy czym częsty lub bardzo częsty kontakt $z$ tym zjawiskiem zadeklarowało ponad $8 \%$. Najwięcej, bo aż $77 \%$, osób deklarujących, że spotykają się z mową nienawiści, miało z nią kontakt $\mathrm{w}$ internecie. Stosunkowo duża grupa badanych spotykała się z nią również na ulicy (48\%) i w przestrzeni publicznej (45\%). Najmniej było wskazań na mowę nienawiści w radiu $(11,7 \%)$, telewizji $(18,5 \%)$ i prasie $(20,1 \%)$.

Ukraińskojęzyczni respondenci częściej niż rosyjskojęzyczni wskazywali, że mają kontakt z mową nienawiści. Ponad $48 \%$ rosyjskojęzycznych badanych deklarowało, że nigdy nie spotykają się z mową nienawiści. W przypadku osób ukraińskojęzycznych było to ponad $38 \%$. W obu grupach podobna liczba osób (8\%) deklarowała częsty lub bardzo częsty kontakt $z$ mową nienawiści. Ponad $38 \%$ osób niestudiujących wskazało, że nigdy nie spotkało się z mową nienawiści skierowaną przeciw Ukraińcom. Takiej samej odpowiedzi udzieliło $43,5 \%$ osób studiujących. W obu grupach ponad $8 \%$ osób badanych zadeklarowało częsty lub bardzo częsty kontakt z nienawistnymi wypowiedziami.

Oddziaływanie mowy nienawiści. W celu zbadania związków ekspozycji na mowę nienawiści ze zdrowiem psychicznym, samooceną, nastrojem i afektem, przeprowadziliśmy analizę korelacji (zob. tabela 1). U tych osób emigrujących z Ukrainy do Polski, które częściej spotykają się z mową nienawiści, występuje większe nasilenie objawów zespołu stresu pourazowego oraz depresji, niższa samoocena oraz wyższy poziom negatywnego afektu. Ekspozycja na mowę nienawiści nie korelowała z pozytywnym afektem. 
Tabela 1

Związki ekspozycji na mowę nienawiści z objawami PTSD, depresją, samooceną oraz negatywnym afektem wśród ukraińskich imigrantów w Polsce

\begin{tabular}{|c|c|c|c|c|c|}
\hline & $\begin{array}{c}\text { Kontakt } \\
\text { z mową } \\
\text { nienawiści }\end{array}$ & $\begin{array}{c}\text { Objawy } \\
\text { PTSD }\end{array}$ & $\begin{array}{l}\text { Objawy } \\
\text { depresji }\end{array}$ & Samoocena & $\begin{array}{c}\text { Negatywny } \\
\text { afekt }\end{array}$ \\
\hline \multicolumn{6}{|l|}{$\begin{array}{l}\text { Kontakt z mową } \\
\text { nienawiści }\end{array}$} \\
\hline Objawy PTSD & $0,22 * * *$ & & & & \\
\hline Objawy depresji & $0,14^{* * *}$ & $0,41^{* * *}$ & & & \\
\hline Samoocena & $-0,10^{*}$ & $-0,27^{* * *}$ & $-0,54^{* * *}$ & & \\
\hline Negatywny afekt & $0,21^{* * *}$ & $0,41^{* * *}$ & $0,62^{* * *}$ & $-0,57^{* * *}$ & \\
\hline Pozytywny afekt & 0,03 & $-0,13^{* * *}$ & $-0,40^{* * *}$ & $0,57^{* * *}$ & $-0,28^{* * *}$ \\
\hline
\end{tabular}

$* p<0,05, \quad * * * p<0,001$

Przeprowadzono również regresję logistyczną, w której przewidywano występowanie traumatyzacji za pomocą częstości kontaktu z mową nienawiści. Moc predykcyjna modelu okazała się istotna $(p<0,001)$, a wyjaśniał on $3 \%$ wariancji traumatyzacji. Ekspozycja na mowę nienawiści okazała się istotnym predyktorem traumatyzacji $b=0,33, S E=0,09, p<0,001$. U osób mających częsty kontakt $z$ mową nienawiści występowało większe prawdopodobieństwo traumatyzacji.

Wyniki wskazują, że większość osób badanych deklaruje kontakt z mową nienawiści. Najczęściej spotykają się z nią w internecie, przestrzeni publicznej i na ulicy. Im częstszy kontakt z krzywdzącymi wypowiedziami na temat grupy, z której pochodzą, mają respondenci, tym większe jest $\mathrm{u}$ nich natężenie negatywnego afektu, objawów zespołu stresu pourazowego i depresji oraz tym niższa samoocena. Wyniki jednoznacznie wskazują na negatywne konsekwencje dla zdrowia kontaktu $z$ mową nienawiści.

Mowa nienawiści a ukrywanie tożsamości. W celu sprawdzenia związków ekspozycji na mowę nienawiści z unikaniem używania języka ukraińskiego/rosyjskiego także przeprowadzono analizę korelacji. Badani, którzy mieli częstszy kontakt z mową nienawiści, częściej unikali mówienia w swoim języku wśród Polaków $(r=0,18, p<0,001)$, ale też rzadziej mówili we własnym języku, gdy przebywali wśród Ukraińców $(r=0,22, p<0,001)$. 
Doświadczenia kontaktu z mową nienawiści wśród zagranicznych studentów Uniwersytetu Warszawskiego

W celu określenia skali kontaktu z mową nienawiści wśród zagranicznych studentów przeprowadziliśmy analizy na zbiorze danych pochodzących z badania studentów zagranicznych studiujących na Uniwersytecie Warszawskim. Badanie prowadzono od stycznia do marca 2018 roku. Była to część większego projektu badawczego „Poczucie bezpieczeństwa wśród studentów zagranicznych UW” dotyczącego dyskryminacji studentów zagranicznych. Projekt obejmował badania jakościowe i ilościowe, a został przeprowadzony na przełomie roku 2017 i 2018 przez zespół koordynowany przez Instytut Studiów Społecznych UW (pod opieką merytoryczną Michała Bilewicza). Studenci zagraniczni otrzymywali kwestionariusz w trzech wersjach językowych: po polsku, angielsku i rosyjsku. Kwestionariusz był dystrybuowany przez uniwersyteckie Biuro Współpracy z Zagranicą (jednostkę zajmującą się obsługą studentów zagranicznych). Część kwestionariusza poświęconą doświadczeniom kontaktu z mową nienawiści wypełniło w sposób kompletny 858 osób, z czego 65,6\% stanowiły kobiety, 33,4\% mężczyźni, a 8 osób zaznaczyło opcję „inna”. Narodowość ukraińską zaznaczyły 183 osoby badane, trzy osoby zaznaczyły dwie narodowości, w tym narodowość ukraińską. Studenci pochodzenia ukraińskiego stanowili największą grupę w badaniu. Drugą grupą pod względem wielkości byli studenci pochodzenia białoruskiego, kolejną studenci pochodzący z Rosji. Badani studenci przyjechali również między innymi z Meksyku, Francji, Chin, Estonii czy Hiszpanii.

Wykorzystane skale. Po serii pytań dotyczących doświadczeń dyskryminacji w przestrzeni uniwersytetu i poza nim (które nie są przedmiotem przedstawianych tu analiz) badanych pytano o doświadczenia kontaktu z mową nienawiści, zadając pytania: Jak często styszysz na terenie Uniwersytetu Warszawskiego nieodpowiednie komentarze o grupie narodowej lub wyznaniowej, do której należysz? oraz Jak często spotykasz się z agresywnymi uwagami ze względu na Twoja narodowość lub wyznanie? Badani udzielali odpowiedzi na skali od 1 - nigdy mi się to nie zdarzyło do $7-z$ darza się to codziennie. W analizach korelacyjnych posługiwano się średnią z odpowiedzi na oba pytania.

Dalsza część kwestionariusza była poświęcona psychospołecznemu funkcjonowaniu zagranicznych studentów. Nasilenie objawów zespołu stresu pourazowego zmierzono za pomocą skali PTSD-8 (Posttraumatic Stress Disorder-8) (Hansen i in. 2010). Skala ta składa się z ośmiu pytań 
$(\alpha=0,74)$. Obejmuje trzy podskale mierzące nadmierną czujność, intruzje oraz unikanie myśli o traumatycznym zdarzeniu. W zastosowanym wariancie skali badani zaznaczali symptomy, które u nich się pojawiły (w oryginalnej wersji skali określane jest nasilenie symptomów).

Samoocenę mierzono za pomocą skali SISE (Single-Item Self-Esteem Scale) (Robins, Hendin, Trzesniewski 2001), w której badani określają poziom ogólnej samooceny na siedmiostopniowej skali odpowiedzi (od 1 $z$ decydowanie nie do $7-z$ decydowanie tak).

Do pomiaru satysfakcji z życia zastosowano Skalę Satysfakcji z Życia (polska wersja Satisfaction with Life Scale SWLS; Diener i in. 1985; Jankowski 2015). Skala składa się z pięciu twierdzeń $(\alpha=0,89)$, na które odpowiadano: od $1-z$ decydowanie nie zgadzam się do $7-z$ decydowanie zgadzam się.

Do pomiaru nastroju wykorzystano skalę PANAS składającą się z dziesięciu pozycji (Thompson 2007). Skala mierzy zarówno afekt negatywny i pozytywny: pięć pozycji skali mierzy afekt negatywny $(\alpha=0,84)$, a pięć innych afekt pozytywny $(\alpha=0,86)$. Osoby badane udzielały odpowiedzi za pomocą siedmiostopniowej skali, w której 1 oznaczało bardzo słabo, a 7 bardzo silnie.

Częstość i miejsca kontaktu z mową nienawiści.

Kontakt z mową nienawiści był mierzony za pomocą dwóch pytań „Jak często słyszysz na terenie Uniwersytetu Warszawskiego nieodpowiednie komentarze o grupie narodowej lub wyznaniowej, do której należysz?" oraz "Jak często na terenie Uniwersytetu Warszawskiego spotykasz się z agresywnymi uwagami ze względu na Twoją narodowość lub wyznanie?”. Wśród studentów zagranicznych $63 \%$ raportowało, że nigdy nie spotkało się z nieodpowiednimi komentarzami wobec ich grupy wyznaniowej bądź narodowościowej, $26 \%$ twierdziło, że spotyka się z nieodpowiednimi komentarzami od czasu do czasu, a $11 \%$ deklarowało kontakt $z$ nieodpowiednimi komentarzami wobec swojej grupy narodowościowej lub wyznaniowej przynajmniej raz w miesiącu. Blisko 50\% respondentów deklarujących kontakt $z$ nieodpowiednimi komentarzami na temat ich grupy narodowej lub wyznaniowej twierdziło, że zdarza się to między zajęciami na uczelni. Z kolei $32 \%$ osób badanych deklarujących styczność z nieodpowiednimi komentarzami wskazywało, że ma kontakt $z$ takimi wypowiedziami podczas trwania zajęć na swoim wydziale lub w swoim instytucie. Pozostałe najczęściej wskazywane miejsca kontaktu z nieodpowiednimi komentarzami to akademiki (26\%) i zajęcia na innych wydziałach (16\%).

Kontakt $z$ agresywnymi uwagami na temat swojej grupy narodowej lub wyznaniowej zadeklarowało ponad $10 \%$ badanych. Osoby badane, które 
zadeklarowały kontakt $\mathrm{z}$ agresywnymi uwagami na temat swojej grupy narodowej lub wyznaniowej najczęściej wskazywały, że są to zdarzenia nieregularne. Osoby te stanowiły $7 \%$ osób badanych deklarujących kontakt $\mathrm{z}$ agresywnymi komentarzami wobec swojej grupy narodowej lub wyznaniowej. Wśród osób spotykających się na Uniwersytecie Warszawskim $z$ agresywnymi wypowiedziami na temat swojej grupy narodowej lub wyznaniowej ponad $60 \%$ wskazało, że ma $\mathrm{z}$ nimi kontakt między zajęciami, $39 \%$ osób spotyka się z nimi podczas zajęć na swoim wydziale, a $34 \%$ osób badanych spotyka się $z$ agresywnymi wypowiedziami na temat swojej grupy narodowej lub wyznaniowej na innych wydziałach. Nieco rzadziej wskazywano na kontakt $z$ agresywnymi uwagami w bibliotekach (18\%) czy w trakcie zajęć wychowania fizycznego (15\%).

W celu zbadania związku pomiędzy ekspozycją na mowę nienawiści a zdrowiem psychicznym, satysfakcją z życia, samooceną oraz afektem przeprowadziliśmy szereg analiz korelacyjnych (zob. tabela 2). U studentów raportujących częstszy kontakt $z$ mową nienawiści częściej występowały objawy zespołu stresu pourazowego (PTSD), $r=0,41, p<0,01$, częściej pojawiał się negatywny nastrój, $r=0,24, p<0,01$ oraz niższy był poziom satysfakcji z życia, $r=-0,13, p<0,01$. Zauważyliśmy również istotny związek negatywny między mową nienawiści a afektem pozytywnym, $r=-0,08, p<0,01$. Nie stwierdziliśmy zaś istotnych związków kontaktu z mową nienawiści z samooceną. Wyniki tych analiz wskazują, że deklarowana przez studentów zagranicznych częstość kontaktu z mową nienawiści przekłada się na wiele wskaźników funkcjonowania psychicz-

Tabela 2

Związki ekspozycji na mowę nienawiści z objawami PTSD, samooceną, satysfakcją z życia, negatywnym i pozytywnym afektem

\begin{tabular}{|c|c|c|c|c|c|}
\hline & $\begin{array}{c}\text { Kontakt } \\
\text { z mową } \\
\text { nienawiści }\end{array}$ & $\begin{array}{c}\text { Objawy } \\
\text { PTSD }\end{array}$ & $\begin{array}{c}\text { Pozytywny } \\
\text { afekt }\end{array}$ & Samoocena & $\begin{array}{c}\text { Negatywny } \\
\text { afekt }\end{array}$ \\
\hline \multicolumn{6}{|l|}{$\begin{array}{c}\text { Kontakt } z \text { mową } \\
\text { nienawiści }\end{array}$} \\
\hline Objawy PTSD & $0,41^{* *}$ & & & & \\
\hline Pozytywny afekt & $-0,08^{*}$ & $-0,05$ & & & \\
\hline Samoocena & 0,10 & $-0,04$ & $0,22^{* *}$ & & \\
\hline Negatywny afekt & $0,24^{* *}$ & $0,30^{* *}$ & $-0,10^{* *}$ & $-0,17^{* *}$ & \\
\hline Satysfakcja z życia & $-0,13^{* *}$ & $-0,17^{* *}$ & $0,29 * *$ & $0,31^{* *}$ & $-0,32^{* *}$ \\
\hline
\end{tabular}

** $p<0,01, \quad * p<0,05$ 
nego. Częstszy kontakt z mową nienawiści wiązał się z występowaniem u studentów niższego poziomu pozytywnego afektu oraz satysfakcji z życia, wyższego poziomu PTSD i negatywnego afektu.

\section{PODSUMOWANIE}

Kontakt cudzoziemców mieszkających w Polsce z mową nienawiści jest dziś powszechny: ponad połowa ukraińskich imigrantów i więcej niż co trzeci zagraniczny student największej polskiej uczelni deklarują, że z powodu swojej obcości mieli do czynienia $z$ wyzwiskami bądź obraźliwymi komentarzami.

Przedstawione dane wskazują, że kontakt $z$ mową nienawiści wiąże się z psychologicznymi i społecznymi konsekwencjami dla cudzoziemców. Osoby, które stykają się z mową nienawiści, deklarują pogorszony nastrój i częściej wykazują objawy PTSD niż osoby niestykające się z mową nienawiści - zauważyliśmy tą prawidłowość zarówno $\mathrm{w}$ próbie studentów zagranicznych, jak i wśród mieszkających w Polsce Ukraińców. Ponadto mowa nienawiści działa w ewidentnie stygmatyzujący sposób - Ukraińcy częściej na nią narażeni unikają posługiwania się własnym językiem w codziennych sytuacjach. Ukrywanie tożsamości w rzeczywistości jest strategią jedynie wzmacniającą stygmatyzację. Badania tego zjawiska wskazują, że próby ukrywania tożsamości jedynie zwiększają odrzucenie danej osoby i paradoksalnie zmniejszają akceptację dla niej wśród grupy większościowej (Newheiser, Barreto 2014). Zważywszy, że żywotność etnojęzykowa jest warunkiem dobrego funkcjonowania społecznego i psychicznego grup imigranckich i mniejszościowych, mowa nienawiści może również tą drogą pośrednio uderzać $\mathrm{w}$ dobrostan cudzoziemców.

Przedstawione badania mają charakter korelacyjny, a zatem opierały się na jednoczesnym pomiarze zmiennych i analizie ich współzmienności. Dlatego nie sposób wnioskować na ich podstawie o faktycznych zależnościach przyczynowych - jednoznaczne stwierdzenie przyczynowości wymagałoby dalszych badań długookresowych czy eksperymentalnych. Jest możliwe, że osoby o gorszym nastroju czy wyższym poziomie depresji dostrzegają w otoczeniu więcej przejawów mowy nienawiści. Jednocześnie trudno spodziewać się takiego kierunku zależności w wypadku zaburzeń z kategorii PTSD. Przyszłe badania na innych próbach imigranckich czy mniejszościowych mogłyby w bardziej jednoznaczny sposób określić kierunek tych zależności. Niezależnie od tych metodologicznych ograniczeń należy podkreślić, że codzienne doświadczenia mowy nienawiści w Polsce są dziś wśród cudzoziemców stosunkowo częste, a jedno- 
cześnie wiążą się z wieloma niekorzystnymi zjawiskami psychospołecznymi.

\section{BIBLIOGRAFIA}

Allport Gordon, 1954, The Nature of Prejudice, Addison-Wesley, Cambridge, MA.

Bilewicz Michał, Marchlewska Marta, Soral Wiktor, Winiewski Mikołaj, 2014, Mowa nienawiści. Raport z badań sondażowych, Fundacja im. Stefana Batorego, Warszawa.

Brown Alexander, 2017, What Is Hate Speech? Part 1: The Myth of Hate, „Law and Philosophy”, t. 36 , s. $419-468$.

Brunarska Zuzanna, Grotte Małgorzata, Lesińska Magdalena, 2012, Migracje obywateli Ukrainy do Polski w kontekście rozwoju społeczno-gospodarczego: stan obecny, polityka, transfery pieniężne, Ośrodek Badań nad Migracjami Uniwersytetu Warszawskiego (http://www.migracje.uw.edu.pl).

Butler Judith, 2010, Walczące słowa. Mowa nienawiści i polityka performatywu, tłum. A. Ostolski, Wydawnictwo Krytyki Politycznej, Warszawa.

Chmielewska Iza, Dobroczek Grzegorz, Panuciak Adam, 2018, Obywatele Ukrainy pracujacy $w$ Polsce - raport z badania, Departament Statystyki NBP, Warszawa.

Crosby Faye, 1984, The Denial of Personal Discrimination, „American Behavioral Scientist”, t. $27(3)$, s. 371-386.

Dąbrowski Paweł (red.), 2012, Praca przymusowa imigrantów w Polsce: Analiza na przykładzie społeczności ukrainskiej i wietnamskiej, Centre of Migration Research, Warszawa.

Diener Ed, Emmons Robert, Larsen Randy, Griffin Sharon, 1985, The Satisfaction with Life Scale, „Journal of Personality Assessment”, t. 49(1), s. 71-75.

Eidheim Harald, 1969, When Ethnic Identity is a Social Stigma, w: Frederik Barth (red.), Ethnic Groups and Boundaries: The Social Organization of Culture Difference, Universitetsforlaget, Oslo.

Evans Carol, 1996, Ethnolinguistic Vitality, Prejudice, and Family Language Transmission, „Bilingual Research Journal", t. 20(2), s. 177-207.

Galloway Fred, Jenkins John, 2005, The Adjustment Problems Faced by International Students in the United States: A Comparison of International Students and Administrative Perceptions at Two Private, Religiously Affiliated Universities, „NASPA Journal”, t. 46(4), s. 175-187.

Giles Howard, Johnson Patricia, 1987, Ethnolinguistic Identity Theory: A Social Psychological Approach to Language Maintenance, „International Journal of Sociology of Language”, t. 68, s. 69-99.

Giles Howard, Ogay Tania, 2007, Communication Accommodation Theory, w: Brian Whaley, Wendy Samter (red.), Explaining Communication: Contemporary Theories and Exemplars, Lawrence Erlbaum, Mahwah, NJ.

Goffman Erving, 2005, Piętno. Rozważania o zranionej tożsamości, [tłum. Joanna Tokarska-Bakir, Aleksandra Dzierżyńska], Gdańskie Wydawnictwo Psychologiczne, Gdańsk.

Hansen Maj, Andersen Tony, Armour Cherie, Elklit Ask, Palic Sabina, Mackrill Thomas, 2010, PTSD-8: A Short PTSD Inventory, „Clinical Practice and Epidemiology in Mental Health", t. 6, s. 101-108.

Jankowski Konrad, 2015, Is the Shift in Chronotype Associated with an Alteration in Well-Being? „Biological Rhythm Research”, t. 46, s. 237-248. 
Jurek Krzysztof, 2018, Stereotypy na temat Ukrainców funkcjonujące w Polsce, w: Michał Lubicz-Miszewski (red.), Imigranci z Ukrainy w Polsce. Potrzeby i oczekiwania, reakcje spoteczne, wyzwania dla bezpieczeństwa, Wydawnictwo Akademii Wojsk Lądowych, Wrocław.

Klebeko Barbara, 2018, Zagrożenia związane z handlem ludźmi. Wykorzystywanie obywateli Ukrainy do pracy przymusowej, w: Michał Lubicz-Miszewski (red.), Imigranci z Ukrainy w Polsce. Potrzeby i oczekiwania, reakcje społeczne, wyzwania dla bezpieczeństwa, Wydawnictwo Akademii Wojsk Lądowych, Wrocław.

Kroenke Kurt, Spitzer Robert, Williams Janet, 2001, The PHQ-9: Validity of a Brief Depression Severity Measure, „Journal of General Internal Medicine”, t. 16(9), s. 606-613.

Leader Tirza, Mullen Brian, Rice Diana, 2009, Complexity and Valence in Ethnophaulisms and Exclusion of Ethnic Out-Groups: What Puts the “Hate” Into Hate Speech? „Journal of Personality and Social Psychology", t. 96(1), s. 170-182.

Lee Jenny, Rice Charles, 2007, Welcome to America? International student perceptions of discrimination, „Higher Education”, t. 53, s. 381-409.

Leets Laura 2002, Experiencing Hate Speech: Perceptions and Responses to Anti-Semitism and Antigay Speech, „Journal of Social Issues”, t. 58(2), s. 341-361.

Leets Laura, Giles Howard, 1997, Words as Weapons: When Do They Wound? Investigations of Harmful Speech, „Human Communication Research”, t. 24(2), s. 260-301.

Leets Laura, Giles Howard, 1999, Harmful Speech in Intergroup Encounters: An Organizational Framework for Communication Research, „Annals of the International Communication Association", t. 22(1), s. 91-137.

Matysiak Ilona, 2014, Ethnic Identity as Stigma in Life Experiences of Different Generations: The Case of Belarusian and Ukrainian Minorities in Poland, „Nationalities Papers: The Journal of Nationalism and Ethnicity", t. 42(6), s. 1002-1014.

Molero Fernando, Fuster Maria, Jetten Jolanda, Moriano Juan, 2011, Living with HIV/AIDS: A Psychosocial Perspective on Coping with Prejudice and Discrimination, ,Journal of Applied Social Psychology", t. 41(3), s. 609-626.

Monzó Lilia, Rueda Robert, 2009, Passing for English Fluent: Latino Immigrant Children Masking Language Proficiency, „Anthropology and Education Quarterly”, t. 40(1), s. 20-40.

Mori Sakurako 2000, Addressing the Mental Health Concerns of International Students, „Journal of Counseling and Development”, t. 78(2), s. 137-144.

Mullen Brian, Rice Diana, 2003, Ethnophaulisms and Exclusion: The Behavioral Consequences of Cognitive Representation of Ethnic Immigrant Groups, „Personality and Social Psychology Bulletin", t. 29, s. 1056-1067.

Mullen Brian, Smyth Joshua, 2004, Immigrant Suicide Rates as a Function of Ethnophaulisms: Hate Speech Predicts Death, „Psychosomatic Medicine”, t. 66(3), s. 343-348.

Newheiser Anna-Kaisa, Barreto Manuela, 2014, Hidden Costs of Hiding Stigma: Ironic Interpersonal Consequences of Concealing a Stigmatized Identity in Social Interactions, „Journal of Experimental Social Psychology", t. 52, s. 58-70.

ODIHR, 2018, Raport $z$ badania: Badanie charakteru $i$ skali niezgłaszanych przestępstw $z$ nienawiści wobec członków wybranych spoteczności w Polsce, Biuro Instytucji Demokratycznych i Praw Człowieka OBWE, Biuro Rzecznika Praw Obywatelskich RP, Warszawa (https://www.osce.org/pl/odihr/412463).

Poyrazli Senel, Lopez Marcos, 2007, An Exploratory Study of Perceived Discrimination and Homesickness: A Comparison of International Students and American Student, „The Journal of Psychology. Interdisciplinary and Applied", t. 141(3), s. 263-280. 
Polko Paulina, 2018, Percepcja bezpieczeństwa obywateli Ukrainy przebywajacych $w$ Polsce $w$ świetle dostępnych badań, w: Michał Lubicz-Miszewski (red.), Imigranci z Ukrainy w Polsce. Potrzeby ioczekiwania, reakcje społeczne, wyzwania dla bezpieczeństwa, Wydawnictwo Akademii Wojsk Lądowych, Wrocław.

Quinn Diane, Earnshaw Valerie, 2013, Concealable Stigmatized Identities and Psychological Well-Being, „Social and Personality Psychology Compass”, t. 7(1), s. 40-51.

Raport, 2017, Raport „Studenci zagraniczni w Polsce 2017”, Fundacja edukacyjna Perspektywy, Warszawa (http://www.studyinpoland.pl/konsorcjum/index.php?option=com_content \&view $=$ article\&id=14515:raport-studenci-zagraniczi-w-polsce-2017\&catid=258:145-n ewsletter-2017\&Itemid=100284).

Robins Richard, Hendin Holly, Trzesniewski Kali, 2001, Measuring Global Self-Esteem: Construct Validation of a Single-Item Measure and the Rosenberg Self-Esteem Scale, „Personality and Social Psychology Bulletin", t. 27(2), s. 151-161.

Rosenberg Morris, 1965, Society and the Adolescent Self-Image, Princeton University Press, Princeton, NJ.

Rosenthal Doreen, Russell Jean, Thomson Gary, 2006, The Health and Wellbeing of International Students at an Australian University, „Higher Education”, t. 55(51), s. 51-67.

Sobański Piotr 2019, Zagadnienie możliwości $i$ celowości zdefiniowania tzw. mowy nienawiści (https://www.researchgate.net/publication/335313156_Zagadnienie_mozliwosci_i_celo wosci_zdefiniowania_tzw_mowy_nienawisci).

Tajfel Henri, Turner John, 1979, An Integrative Theory of Intergroup Conflict, w: W. G. Austin, S. Worchel (red.), The Social Psychology of Intergroup Relations, Brooks-Cole, Monterey, CA.

Thompson Edmund, 2007, Development and Validation of an Internationally Reliable Short-Form of the Positive and Negative Affect Schedule (PANAS), ,Journal of Cross-Cultural Psychology”, t. 38(2), s. 227-242.

Tyma Piotr (red.), 2019, Mniejszość ukraińska i migranci z Ukrainy w Polsce. Analiza dyskursu, Związek Ukraińców w Polsce, Warszawa.

Valenta Marko, 2009, Immigrants' Identity Negotiations and Coping with Stigma in Different Relational Frames, „Symbolic Interaction”, t. 32(4), s. 351-371.

Watson David, Clark Lee Anna, Tellegen Auke, 1988, Development and Validation of Brief Measure of Positive and Negative Affect: PANAS Scale, ,Journal of Personality and Social Psychology”, t. 54(6), s. 1063-1070.

Winiewski Mikołaj, Hansen Karolina, Bilewicz Michał, Soral Wiktor, Świderska Aleksandra, Bulska Dominika, 2017, Mowa nienawiści, mowa pogardy Raport z badania przemocy werbalnej wobec grup mniejszościowych, Fundacja Stefana Batorego, Warszawa.

Wiśniewski Daniel, 2018, Sposób postrzegania studentów ukraińskich przez ich kolegów z Polski jako konsekwencja „ukrainizacji” Uniwersytetu Opolskiego, w: Michał Lubicz-Miszewski (red.), Imigranci z Ukrainy w Polsce. Potrzeby i oczekiwania, reakcje społeczne, wyzwania dla bezpieczeństwa, Wydawnictwo Akademii Wojsk Lądowych, Wrocław.

$*$

Studentka miała obrażać Ukrainkę. Zareagowała uczelnia, prokuratura wszczęła dochodzenie, 26 listopada 2019, tvn24.pl (https://tvn24.pl/wiadomosci-z-kraju,3/olsztyn-studentka-obraza la-ukrainke-w-internecie-dochodzenie-prokuratury-reakcja-uczelni, 988427.html?h=2e 2f). 
Pobili kierowce Ubera. Bo jest Ukraińcem i nie właczyt disco polo, 10 marca 2019, wyborcza.pl (https://warszawa.wyborcza.pl/warszawa/7,54420,24536030,pobili-kierowce-ubera-bo -jest-ukraincem-i-nie-wlaczyl-disco.html)

Wroctawianie i Caritas wspierają Ukraińca przejechanego przez taksówkarza, 4 maja 2019, wyborcza.pl (https://wroclaw.wyborcza.pl/wroclaw/7,35771,24751392,wroclawianie-i-carita s-wspieraja-ukrainca-przejechanego-przez.html).

\title{
Akty prawne
}

Mowa nienawiści. Prawo polskie (http://www.mowanienawisci.info/sekcja/polskie [02.10. 2020]).

Mowa nienawiści wg Rady Europy (http://www.mowanienawisci.info/post/rada-europy [02.10. 2020]).

\section{HATE SPEECH AS STIGMATIZATION: THE EXPERIENCE OF HATE SPEECH AMONG FOREIGN STUDENTS AND IMMIGRANTS IN POLAND}

\author{
Michał Wypych, Kamila Zochniak, Michał Bilewicz \\ (Warsaw University)
}

\begin{abstract}
Hate speech can have very serious consequences for the health of its victims and may also be associated with stigmatization and with forcing members of a group to hide their identity. Groups that often encounter hate speech in Poland are Ukrainians and foreign students at Polish universities. The results of two studies conducted among economic immigrants from Ukraine and foreign students at the University of Warsaw indicate a relationship between exposure to hate speech and the occurrence of post-traumatic stress disorder, more severe symptoms of depression, lower self-esteem, and negative affect. Among immigrants from Ukraine, more frequent contact with hate speech was also associated with avoiding the use of their native language in the presence of Poles and other Ukrainians. The research results clearly show the negative consequences of hate speech.
\end{abstract}

key words: hate speech, mental health, stigmatization, immigrants

stowa kluczowe: mowa nienawiści, zdrowie psychiczne, stygmatyzacja, imigranci 